Sains Malaysiana 47(9)(2018): 2091-2098

http://dx.doi.org/10.17576/jsm-2018-4709-17

\title{
Kesan Garam Litium Nitrat terhadap Sifat Elektrokimia Karboksimetil Kitosan
}

(The Effect of Lithium Nitrate towards Electrochemical Properties of Carboxymethyl Chitosan)

\author{
N.N. MobaraK*,F.N. JanTAN, N.A. DZUlKuRnain, A. AhMAD \& M.P. AbDULlah
}

\section{ABSTRAK}

Karboksimetil kitosan menunjukkan potensi untuk digunakan sebagai polimer induk bagi aplikasi elektrolit polimer pepejal.Kesan garam litium nitrat terhadap sifat elektrokimia elektrolit polimer pepejal berasaskan karboksimetil kitosan telah dijalankan. Elektrolit polimer pepejal berasaskan karboksimetil kitosan disediakan melalui teknik pengacuan larutan dengan nisbah garam litium nitrat $\left(\mathrm{LiNO}_{3}\right)$ yang berbeza. Pencirian filem telah dijalankan dengan menggunakan spektroskopi inframerah transformasi Fourier-pantulan penuh kecil (ATR-FTIR) dan Spektroskopi Impedans Elektrokimia (EIS) bagi penentuan interaksi kimia dan sifat elektrokimia polimer elektrolit tersebut. Spektrum ATR-FTIR menunjukkan ion litium cenderung untuk berinteraksi dengan kumpulan karbonil dan kumpulan ester dalam struktur karboksimetil kitosan. Kekonduksian ion tertinggi yang dicapai adalah $8.44 \times 10^{-4} \mathrm{~S} \mathrm{~cm}^{-1}$ dengan kepekatan garam $30 \mathrm{bt} . \% \mathrm{LiNO}$ pada suhu bilik dan $5.25 \times 10^{-3} \mathrm{~S} \mathrm{~cm}^{-1}$ pada suhu $70^{\circ} \mathrm{C}$. Filem karboksimetil kitosan-30\% LiNO mencapai kestabilan secara elektrokimia sehingga 2.94 V. Keputusan kajian yang diperoleh menunjukkan elektrolit polimer pepejal berasaskan karboksimetil kitosan memberi satu tarikan baru bagi aplikasi bateri ion litium.

Kata kunci: Elektrolit polimer pepejal; FTIR; karboksimetil kitosan; sifat elektrokimia

\section{ABSTRACT}

Carboxymethyl chitosan has showed its potential to be used as host polymer for solid polymer electrolyte application. The effect of lithium nitrate towards electrochemical properties of solid polymer electrolyte based carboxymethyl chitosan has been investigated. Solid bio-polymer electrolyte based carboxymethyl chitosan was prepared by solution-casting technique with different ratios of lithium nitrate $\left(\mathrm{LiNO}_{3}\right)$ salt. The films were characterized by attenuated total reflected Fourier transform infrared (ATR-FTIR) Spectroscopy and Electrochemical Impedance Spectroscopy to determine the chemical interaction and electrochemical properties of the polymer electrolytes. Based on ATR-FTIR spectra, the lithium ions tend to interact with carbonyl group and ether group in carboxymethyl chitosan structure. The highest conductivity achieved was $8.44 \times 10^{-4} \mathrm{~S} \mathrm{~cm}^{-1}$ with a concentration of $30 \mathrm{wt} . \%$ of LiNO $\mathrm{S}_{3}$ salt at room temperature and $5.25 \times 10^{-3} \mathrm{~S}$ $\mathrm{cm}^{-1}$ at $70^{\circ} \mathrm{C}$. The films were electrochemically stable up to $2.94 \mathrm{~V}$. The results suggest that this solid polymer electrolyte based on carboxymethyl chitosan demonstrate potential to be applied in lithium ion batteries.

Keywords: Carboxymethyl chitosan; electrochemical properties; FTIR; solid polymer electrolyte

\section{PENGENALAN}

Pada alaf ini, penggunaan teknologi seperti komputer, telefon bimbit dan kenderaan memainkan peranan penting dalam kehidupan seharian manusia. Alat penyimpanan dan penukar tenaga seperti sel bateri dan sel suria memastikan setiap alat peranti ini dapat berfungsi dengan baik. Sel ini mempunyai peranan untuk menukarkan tenaga kimia kepada tenaga elektrik berasaskan kepada prinsip perbezaan kepekatan elektron dan keupayaan elektrik. Selain elektrod, elektrolit adalah antara komponen penting di dalam setiap sel. Elektrolit yang pada kebiasaannya dalam keadaan larutan mengandungi ion dan ia berfungsi sebagai satu medium pengangkutan ion. Bagi menghasilkan sel berprestasi tinggi, elektrolit yang digunakan haruslah mempunyai kekonduksian ion yang tinggi serta mempunyai kestabilan dengan elektrod.

Walau bagaimanapun, kejadian kebakaran bateri yang dialami oleh Japan Airlines Boeing 787 Dreamliners pada awal tahun 2013 menunjukkan kelemahan penggunaan elektrolit cecair (Hargreaves 2013). Kejadian ini disumbangkan oleh faktor penggunaan pelarut organik mudah terbakar untuk aplikasi bateri. Selain itu, elektrolit cecair juga berhadapan dengan masalah kehilangan yang berlaku sama ada melalui kebocoran atau penyejatan. Keadaan ini akan mengakibatkan jangka hayat sel bateri atau sel suria terhad. Ini mendorong para penyelidik dan pengusaha dalam bidang aplikasi alat peranti ke arah penggunaan elektrolit dalam keadaan pepejal. Elektrolit polimer pepejal (EPP) adalah terdiri daripada garam dan polimer dengan polimer bertindak sebagai pelarut. Penggunaan EPP mempunyai kelebihan daripada segi lekatan dengan elektrod serta kemudahan dalam proses fabrikasi penghasilan sel yang lebih kecil.

Memandangkan isu berkaitan alam sekitar mula menarik perhatian umum, penggunaan polimer induk yang mempunyai ciri mesra alam akan mempunyai kelebihan 
berbanding polimer sintetik. Oleh itu, kitosan dipilih untuk digunakan sebagai polimer induk dalam kajian ini. Kajian oleh Hoek (1995) dan Hudson dan Smith (1998) menunjukkan bahawa polimer ini dikategorikan sebagai polimer yang tidak toksik kepada alam sekitar dan boleh terbiodegradasi. Polimer yang boleh diperoleh di Malaysia ini adalah hasil ekstrak daripada haiwan krustasea (kitosan). Penggunaan polimer terbiodegradasi mempunyai faedah ekonomi dan alam sekitar kepada negara. Selain itu, penggunaan polimer semula jadi sebagai polimer induk merupakan pengganti yang baik untuk bahan-bahan yang sedia ada di dalam usaha membangunkan teknologi hijau (Khanmirzaei \& Ramesh 2013).

Secara amnya, kitosan adalah polimer separuhhablur yang dikategorikan sebagai polisakarida (Croisier \& Jérôme 2013). Kitosan mempunyai kumpulan amina yang akan terproton apabila dilarutkan di dalam asid lewis lemah. Penggantian kumpulan karboksimetil yang dilakukan menggunakan kaedah pengalkilan secara terus terhadap rantai kitosan. Penambahan kumpulan karboksimetil dilakukan bukan sahaja akan meningkatkan bilangan oksigen pada rantai polimer, ia juga untuk mengurangkan fasa kehabluran di dalam rantai polimer induk (Masykur et al. 2014).

Kajian ini dijalankan untuk memahami kesan penambahan garam litium nitrat $\left(\mathrm{LiNO}_{3}\right)$. Garam litium seperti litium perklorat $\left(\mathrm{LiClO}_{4}\right)$, litium tetrafluoroborat $\left(\mathrm{LiBF}_{4}\right)$, litium bis(trifluorometanasulfonil) imida (LiTSFl) dan litium heksafluorofosfat $\left(\mathrm{LiPF}_{6}\right)$ adalah antara garam litium yang telah digunakan dalam beberapa kajian yang lepas. Potensi garam $\mathrm{LiNO}_{3}$ telah dilaporkan oleh Mohamed et al. (1995) menggunakan kitosan terasetil sebagai polimer induk yang mencapai kekonduksian elektrik $2.7 \times 10^{-4} \mathrm{~S} \mathrm{~cm}^{-1}$. Xiong et al. (2012) juga menunjukkan penggunaan $\mathrm{LiNO}_{3}$ sebagai bahan tambah berkesan yang dapat melindungi anod litium. Dalam kajian ini, kesan garam litium nitrat terhadap sifat elektrokimia karboksimetil kitosan dianalisis menggunakan spektroskopi impedans elektrokimia dan spektroskopi inframerah untuk memahami interaksi yang berlaku di antara garam litium nitrat dengan karboksimetil kitosan.

\section{BAHAN KIMIA DAN KAEDAH}

\section{BAHAN KIMIA}

Kitosan diperoleh secara komersial daripada ChitoChem. Natrium hidroksida, isopropanol and asid monokloroasetik diperoleh daripada Sigma Aldrich. Kesemua bahan kimia digunakan tanpa proses penulenan lanjutan.

\section{PENYEDIAAN SERBUK KARBOKSIMETIL KITOSAN}

Terbitan karboksimetil kitosan disediakan berdasarkan kepada kaedah yang dicadangkan oleh Sun et al. (2008). Kitosan (10 g), natrium hidroksida (10 g), air suling $(50 \mathrm{~mL})$ dan isopropanol $(50 \mathrm{~mL})$ dituangkan ke dalam kelalang kon $500 \mathrm{~mL}$. Asid monokloroasetik (15 g) dilarutkan di dalam isopropanol $(20 \mathrm{~mL})$. Larutan ini ditambah ke dalam campuran larutan ampaian kitosan dan dibiarkan bertindak balas selama 4 jam pada suhu $50^{\circ} \mathrm{C}$. Tindak balas diberhentikan dengan penambahan larutan $70 \%$ etil alkohol (100 mL). Campuran tindak balas dituras dan dibilas menggunakan 70-90\% etil alkohol. Serbuk yang diperoleh dikeringkan di dalam desikator (Mobarak et al. 2013).

\section{PENYEDIAAN MEMBRAN POLIELEKTROLIT}

Larutan karboksimetil kitosan disediakan dengan melarutkan karboksimetil kitosan ke dalam larutan asid asetik dengan kepekatan yang berbeza-beza. Selepas proses perlarutan, larutan dituang ke dalam petri kaca dan dibiarkan kering pada suhu bilik di dalam kebuk wasap sehingga lapisan terbentuk. Filem yang terbentuk akan disimpan di dalam desikator untuk proses pengeringan yang seterusnya. Ketebalan bagi filem yang terbentuk akan diukur menggunakan angkup vernier jenama Mitutoyo.

\section{PENYEDIAAN ELEKTROLIT POLIMER PEPEJAL}

Elektrolit polimer pepejal disediakan dengan melarutan karboksimetil kitosan (1 g) di dalam larutan asetik asid $1 \%$ (50 mL) dengan pengacauan berterusan selama 24 jam pada suhu bilik. Garam $\mathrm{LiNO}_{3}$ dengan kepekatan yang berbeza (5-30\%) dilarutkan berasingan di dalam larutan asid asetik 1\% (10 mL) selama sejam. Larutan garam kemudiannya ditambahkan ke dalam larutan polimer dan dikacau selama 24 jam. Campuran larutan dituang ke dalam petri kaca dan dibiarkan kering di dalam kebuk wasap. Filem yang terbentuk akan disimpan dalam desikator sebelum pencirian seterusnya dijalankan. Ketebalan bagi filem yang terbentuk akan diukur menggunakan angkup vernier jenama Mitutoyo.

\section{PENCIRIAN KARBOSIMETIL KITOSAN}

Analisis ATR-FTIR dijalankan dengan menggunakan Perkin Elmer Spectrum 2000 dalam julat nombor gelombang antara 4000 hingga $400 \mathrm{~cm}^{-1}$ dengan resolusi imbasan $4 \mathrm{~cm}^{-1}$. Analisis ini dijalankan bagi mengkaji interaksi yang wujud antara polimer matriks dan litium nitrat berdasarkan perubahan kumpulan berfungsi. Pengukuran impedans arus ulang-alik dijalankan dengan menggunakan Penganalisis Rangsangan Frekuensi Tinggi (HFRA1255) dan Pengantaramuka elektrokimia (SI1266) berjenama Solartron Sclumberger dalam julat frekuensi antara 100 $\mathrm{Hz}$ hingga $1 \mathrm{MHz}$ dengan amplitud voltan ulang alik 100 $\mathrm{mV}$. Polimer elektrolit diapit antara dua elektrod keluli tahan karat dengan luas permukaan bersentuhan $2.0 \mathrm{~cm}^{2}$. Rintangan pukal $\left(R_{b}\right)$ dikira berdasarkan analisis litar setara dengan menggunakan perisian penganalisis $\mathrm{Z}_{\text {view }}$. Nilai kekonduksian $(\sigma)$ dikira berdasarkan persamaan $\boldsymbol{\sigma}=t \cdot R_{\mathrm{b}}{ }^{-1} \cdot A^{-1}$ dengan $t$ adalah ketebalan membran filem $(\mathrm{cm})$ dan $A$ adalah luas permukaan sampel yang bersentuhan dengan elektrod $\left(\mathrm{cm}^{2}\right)$. Analisis spektroskopi impedans elektrokimia (EIS) dijalankan pada suhu bilik. 
Kebergantungan suhu kekonduksian arus ulang alik direkod pada suhu di antara $30^{\circ} \mathrm{C}$ hingga $80^{\circ} \mathrm{C}$ dengan selang suhu $10^{\circ} \mathrm{C}$. Analisis volatammetri sapu lelurus bagi elektrolit bio-polimer pepejal dilakukan dengan menggunakan potensi DC $(0.1 \mathrm{~V})$ dengan filem elektrolit diletakkan antara dua elektrod keluli tahan karat. Analisis ini menggunakan instrumen elektrokimia berbilang saluran pada suhu $303 \mathrm{~K}$.

\section{KEPUTUSAN DAN PERBINCANGAN}

\section{KAJIAN KEKONDUKSIAN ION PADA SUHU BILIK}

Peningkatan kekonduksian ion dengan kehadiran garam litium nitrat $\left(\mathrm{LiNO}_{3}\right.$ ) dalam karboksimetil kitosan ditunjukkan dalam Rajah 1(A). Kekonduksian ion didapati meningkat dengan penambahan 30 bt. \% garam $\mathrm{LiNO}_{3}$ dalam karboksimetil kitosan dengan peningkatan daripada $1.48 \times 10^{-7} \mathrm{~S} \mathrm{~cm}^{-1}$ kepada $8.44 \times 10^{-4} \mathrm{~S} \mathrm{~cm}^{-1}$. Peningkatan kekonduksian ion ini boleh dikaitkan dengan penambahan ion bebas dalam polimer dengan peningkatan kepekatan garam (Wu et al. 2009). Peningkatan darjah penceraian ion dengan peningkatan mol garam dibuktikan melalui analisis penceraian yang ditunjukkan pada Rajah 1(B).

Peningkatan ion bebas di dalam polimer semakin banyak menjadikan kadar cas yang dipindahkan lebih besar dan meningkatkan kekonduksian ion (Denaro 1987). Ini dapat dijelaskan berdasarkan kekonduksian ion yang dinyatakan dalam (1).

$$
\sigma=\Sigma \mu_{\mathrm{i}} \mathrm{n}_{\mathrm{i}} \mathrm{q}_{\mathrm{i}}
$$

dengan $\mu$ ialah kemudahgerakan spesies $\mathrm{i}$; $\mathrm{n}$ ialah kepekatan pembawa bagi spesies i/ketumpatan pembawa cas yang bergerak; dan q ialah cas spesies i.

Oleh itu, sebarang peningkatan pada $\mathrm{n}$ atau $\mu$ akan meningkatkan kekonduksian ion (Osman et al. 2012; Rudhziah et al. 2016; Singh et al. 2016). Berdasarkan kepada Rajah 1(B), darjah penceraian ion meningkat daripada $5 \mathrm{~mol} \mathrm{LiNO}_{3}$ kepada $30 \mathrm{~mol} \mathrm{LiNO}_{3}$. Penceraian
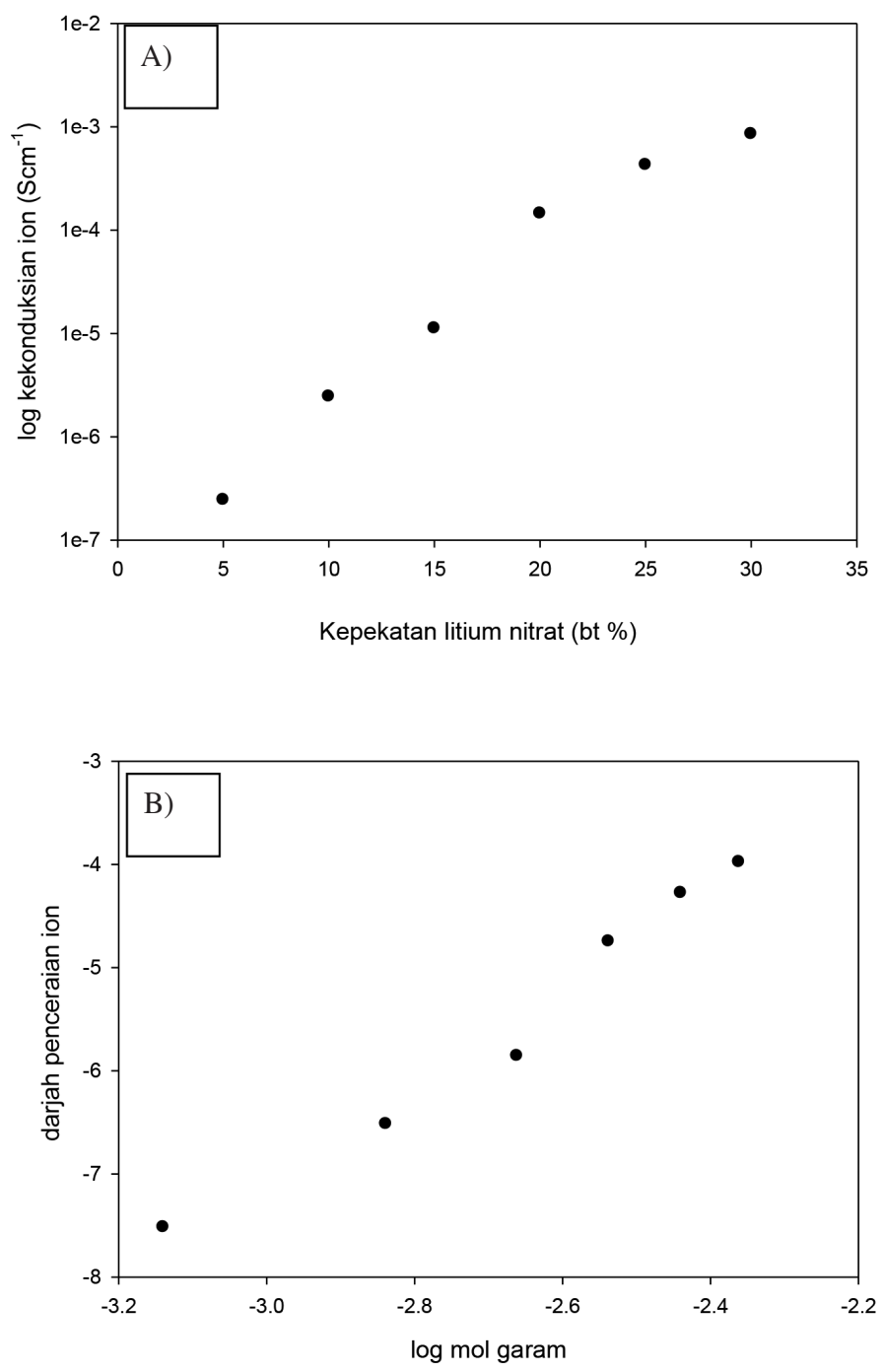

RAJAH 1. Graf log kekonduksian ion melawan kepekatan litium nitrat bagi karboksimetil kitosan (A) dan graf log darjah penceraian ion melawan log mol litium nitrat bagi karboksimetil kitosan (B) 
garam $\mathrm{LiNO}_{3}$ dalam rantai karboksimetil kitosan berlaku apabila terdapat interaksi yang berlaku antara kumpulan berfungsi $\mathrm{COO}^{-}$dan $\mathrm{C}-\mathrm{O}-\mathrm{C}$. Ini disokong berdasarkan kepada keputusan pencirian spektroskopi ATR-FTIR. Apabila kepekatan garam semakin tinggi, interaksi yang berlaku bertambah menjadikan bilangan ion $\mathrm{Li}^{+}$bebas bertambah seterusnya meningkatkan kekonduksian ion (Mobarak et al. 2015).

Peningkatan darjah penceraian ion dengan pertambahan kepekatan garam juga dibuktikan dengan peningkatan nilai kemudahgerakan ion $\mathrm{LiNO}_{3}$ dalam rantai karboksimetil kitosan seperti yang ditunjukkan dalam Jadual 1. Nilai kemudahgerakan ion ini diukur menggunakan Hukum Kuasa pada (2) (Hanibah et al. 2014) dengan $\kappa, \mu^{\prime}, \boldsymbol{\gamma}$ dan $\boldsymbol{\lambda}$ 。 serta $\mathrm{C}_{\text {garam }}$ masing-masing mewakili kekonduksian elektrolit, kemudahgerakan ion, kecerunan daripada graf serta kepekatan garam. Seterusnya, nilai kemudahgerakan bagi kation dan anion dikira menggunakan (3) dan (4) dengan $\mu_{+}$dan $\mu_{-}$adalah nilai kemudahgerakan kation dan anion, $\mu_{+}$dan $\mu_{-}$adalah nilai relatif kemudahgerakan kation dan anion di dalam keadaan akueus serta $\mu$ adalah jumlah kemudahgerakan. Nilai pekali resapan bagi kation dan anion pula dikira menggunakan (5) dengan $\mathrm{K}_{\mathrm{B}}$ adalah pemalar Boltzman, T adalah suhu (K), Q adalah cas ion serta $\mu$ adalah nilai kemudahgerakan ion.

$$
\begin{aligned}
& \log \kappa=\mu^{\prime}+\gamma \lambda_{o} \gamma C_{\text {garam }} \\
& \mu_{+}=\left(\mu_{+}(a q) / \mu_{+}+\mu_{-}\right) \times \mu \\
& \mu_{-}=\left(\mu_{-}(a q) / \mu_{+}+\mu_{-}\right) \times \mu \\
& D=\left(K_{B} T / Q\right) \mu
\end{aligned}
$$

Jadual 1 menunjukkan kemudahgerakan kation dan anion dalam rantai karboksimetil kitosan meningkat dengan penambahan garam $\mathrm{LiNO}_{3}$ iaitu masing-masing daripada $5.78 \times 10^{-10} \mathrm{~cm}^{2} \mathrm{~V}^{-1} \mathrm{~s}^{-1}$ kepada $2.36 \times 10^{-7} \mathrm{~cm}^{2} \mathrm{~V}^{-1}$ $\mathrm{s}^{-1}$ untuk kation dan $6.77 \times 10^{-11} \mathrm{~cm}^{2} \mathrm{~V}^{-1} \mathrm{~s}^{-1}$ kepada $4.36 \times$ $10^{-7} \mathrm{~cm}^{2} \mathrm{~V}^{-1} \mathrm{~s}^{-1}$ untuk anion. Kemudahgerakan dan resapan anion dalam karboksimetil kitosan adalah lebih tinggi berbanding kation, selari dengan peningkatan peratusan kepekatan garam $\mathrm{LiNO}_{3}$. Ini menunjukkan bahawa anion memainkan peranan yang penting bagi kekonduksian ion karboksimetil kitosan-LiNO . Walaupun secara amnya, semakin besar saiz semakin lambat pergerakan, namun dapat dilihat bahawa pergerakan anion adalah lebih tinggi berbanding kation. Keadaan ini disebabkan wujudnya tenaga tolakan antara anion, ion nitrat dan ion karboksil yang terdapat pada rantai karboksimetil kitosan. Walau bagaimanapun, pergerakan ion litium hanya melalui interaksi dengan kumpulan karbonil, eter atau melalui pembentukan ikatan ionik antara ion litium dengan ion karboksil.

Seterusnya, Rajah 2 menunjukkan peningkatan kekonduksian ion dapat apabila berlaku peningkatan suhu antara $30^{\circ} \mathrm{C}$ hingga $80^{\circ} \mathrm{C}$. Kesan suhu ke atas karbosimetil kitosan-30 bt. \% $\mathrm{LiNO}_{3}$ dilakukan bagi memahami mekanisma pergerakan ion di dalam rantai. Nilai korelasi bagi Model VTF $(r=0.98)$ adalah lebih tinggi berbanding model Arrhenius $(r=0.94)$. Hal ini menunjukkan bahawa pergerakan ion di dalam rantai karboksimetil kitosan-30 bt. $\% \mathrm{LiNO}_{3}$ berkait dengan pergerakan rantai segmen yang menyebabkan peningkatan isi padu bebas polimer induk. Hal ini disebabkan molekul segmen memperoleh lebih banyak tenaga getaran (Abdullah et al. 2018). Keadaan ini akan meningkatkan kebolehgerakan ion melalui interaksi dengan polimer segmen seterusnya meningkatkan kekonduksion ion. Rudhziah et al. (2016) menyatakan bahawa peningkatan kekonduksian ion dengan suhu dapat dijelaskan berdasarkan mekanisma loncatan di antara tapak pengkoordinatan, struktur pengenduran setempat dan pergerakan segmen polimer. Apabila isi padu bebas bertambah dengan peningkatan suhu, rantai polimer memperoleh sistem dalaman yang lebih cepat dengan putaran ikatan menghasilkan gerakan segmen. Ini menggalakkan loncatan ion dalam rantai dan ruang antara rantai serta meningkatkan kekonduksian polimer elektrolit. Kekonduksian ion tertinggi yang diperoleh bagi karbosimetil kitosan-30 bt. $\% \mathrm{LiNO}_{3}$ adalah $5.25 \times 10^{-3} \mathrm{~S}$ $\mathrm{cm}^{-1}$ pada suhu $70^{\circ} \mathrm{C}$.

\section{KAJIAN PEMALAR DIELEKTRIK KEBERGANTUNGAN FREKUENSI}

Kajian dielektrik dijalankan ke atas karboksimetil kitosan-30\% LiNO $_{3}$. Plot graf bagi pemalar dielektrik dengan kebergantungan frekuensi yang tertentu $(\log f)$ pada suhu yang berbeza ditunjukkan dalam Rajah 3(a) manakala plot graf kehilangan dielektrik dengan kebergantungan frekuensi $(\log f)$ pada suhu berbeza ditunjukkan dalam Rajah 3(b). Pemalar dielektrik $\varepsilon$ ' adalah cas yang tersimpan dalam suatu bahan manakala kehilangan dielektrik $\varepsilon$ " adalah ukuran tenaga yang hilang untuk menggerakan ion apabila kepolaran medan elektrik bertukar dengan laju (Ahmad \& Isa 2016). Pemalar dielektrik dan kehilangan

JADUAL 1. Ringkasan nilai kemudahgerakan dan pekali resapan kation dan anion bagi sistem karboksimetil kitosan- $\mathrm{LiNO}_{3}$

\begin{tabular}{lcccc}
\hline \multirow{2}{*}{\multicolumn{1}{c}{ Sampel }} & \multicolumn{2}{c}{ Kemudahgerakan ion $\left(\mathrm{cm}^{2} \mathrm{~V}^{-1} \mathrm{~s}^{-1}\right)$} & \multicolumn{2}{c}{ Pekali resapan $\left(\mathrm{cm}^{2} \mathrm{~s}^{-1}\right)$} \\
\cline { 2 - 5 } & Kation & Anion & Kation & Anion \\
\hline Karboksimetil kitosan & $5.78 \times 10^{-10}$ & $6.77 \times 10^{-11}$ & $2.38 \times 10^{-30}$ & $2.79 \times 10^{-31}$ \\
Karboksimetil kitosan-LiNO & $2.36 \times 10^{-7}$ & $4.36 \times 10^{-7}$ & $9.71 \times 10^{-28}$ & $1.79 \times 10^{-27}$ \\
\hline
\end{tabular}




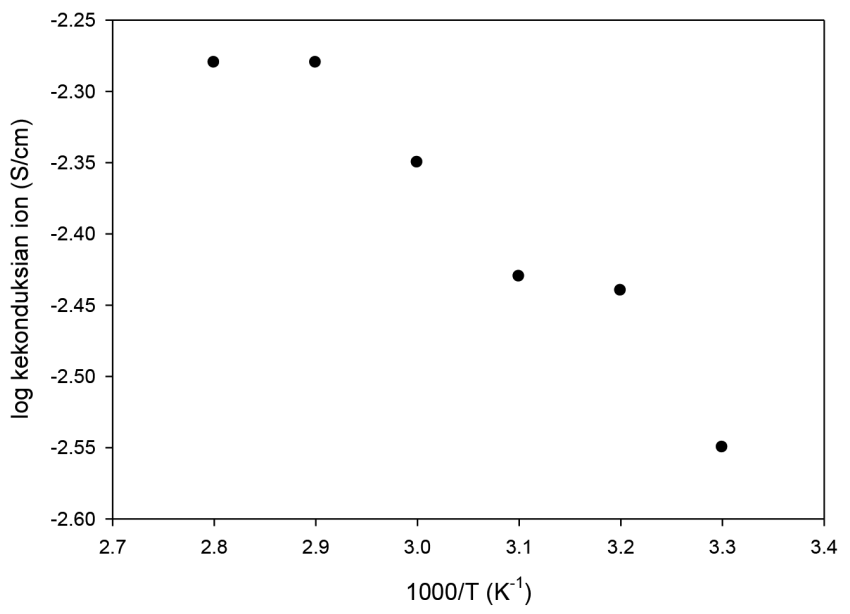

RAJAH 2. Kesan suhu terhadap kekonduksian ion bagi karboksimetil kitosan -30 bt. \% $\mathrm{LiNO}_{3}$

dielektrik dikira dengan menggunakan data impedans berdasarkan (6):

$$
\begin{aligned}
& \varepsilon_{r}^{*}=\frac{1}{j \omega C_{0} Z^{*}} \\
& \varepsilon^{\prime}-j \varepsilon^{\prime \prime}=\frac{z^{\prime \prime}}{\omega C_{0}\left(Z^{\prime 2}+Z^{\prime \prime 2}\right)}-j \frac{z^{\prime}}{\omega C_{0}\left(Z^{\prime 2}+Z^{\prime \prime 2}\right)}
\end{aligned}
$$

dengan $Z^{*}$ ialah impedans kompleks; $C_{0}$ ialah kapasitans vakum $\left(C_{0}={ }^{\varepsilon_{0 A} / d}\right)$; d ialah ketebalan filem elektrolit; A ialah luas permukaan sentuhan; dan $\omega$ ialah frekuensi bersudut $(\omega=2 \pi f)$.

Berdasarkan Rajah 3(a), dapat dilihat bahawa nilai pemalar $\varepsilon$ ' adalah tinggi pada frekuensi rendah dan menurun pada frekuensi yang tinggi. Nilai pemalar $\varepsilon$ ' yang tinggi pada frekuensi rendah adalah disebabkan oleh orientasi kumpulan polar, ion-ion dan pengkutuban ruang cas pada julat frekunesi rendah. Ia juga dapat dilihat bahawa nilai pemalar $\varepsilon$ ' meningkat apabila suhu meningkat dan mempunyai nilai yang paling tinggi pada suhu $80^{\circ} \mathrm{C}$. Ini adalah disebabkan oleh peningkatan ketumpatan cas pembawa yang terhasil daripada pemisahan garam di dalam matriks polimer. Nilai pemalar $\varepsilon$ ' didapati menurun pada frekuensi yang tinggi kerana pergerakan ulang-alik dwikutub menjadi lambat kerana tidak sejajar dengan medan elektrik yang digunakan. Fenomena ini dikenali sebagai proses santaian elektrik (Zamri et al. 2014). Proses santaian elektrik ini adalah disebabkan oleh penurunan pengumpulan cas yang menyebabkan penurunan pemalar dielektrik dan kehilangan pemalar dielektrik.

Manakala Rajah 3(b) pula, dapat dilihat bahawa nilai kehilangan pemalar $\varepsilon$ " adalah tinggi pada frekuensi rendah dan menurun pada frekuensi yang tinggi. Nilai kehilangan pemalar $\varepsilon$ " yang tinggi adalah disebabkan oleh kesan pengkutuban pada elektrod dan kemudahgerakan cas bebas yang berkait rapat dengan kekonduksian ion, $\sigma$ sampel. Nilai kehilangan pemalar $\varepsilon$ " juga meningkat apabila suhu meningkat dan mempunyai nilai yang paling tinggi pada suhu $80^{\circ} \mathrm{C}$. Ini adalah disebabkan oleh penghasilan (a)

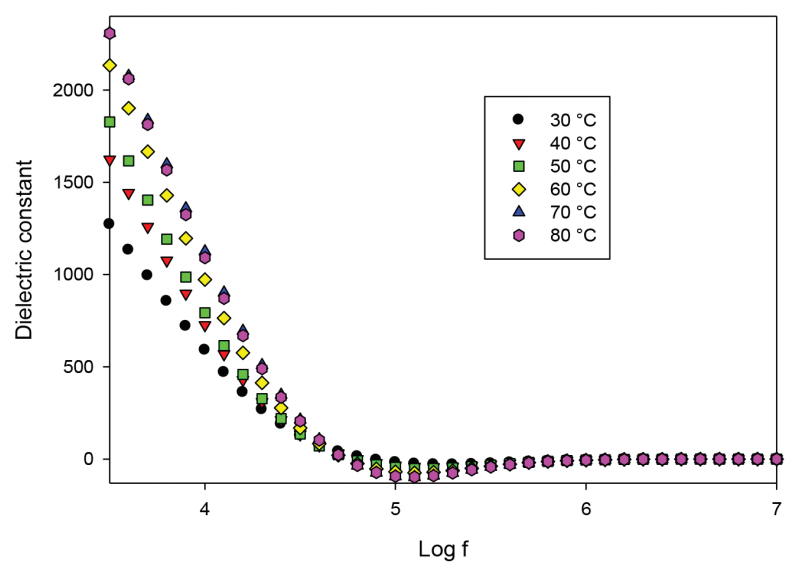

(b)

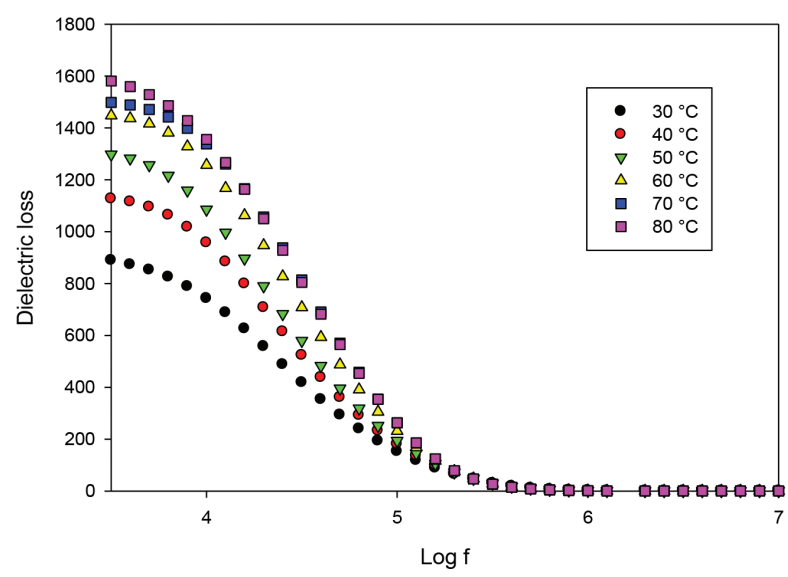

RAJAH 3. (a) Pemalar dielektrik bagi karboksimetil kitosan -30\% $\mathrm{LiNO}_{3}$ pada suhu berbeza dan (b) kehilangan dielektrik bagi karboksimetil kitosan $-30 \% \mathrm{LiNO}_{3}$ pada suhu berbeza

pelepasan tenaga yang besar hasil daripada ketumpatan cas pembawa (ion garam yang telah terpisah) yang terlalu banyak. Nilai kehilangan pemalar $\varepsilon$ " yang menurun pada 
frekuensi tinggi pula adalah disebabkan oleh pembalikan berkala medan yang tinggi pada medan di bahagian permukaan. Kesan ion terhadap modulus elektrik menurun disebabkan oleh penurunan penyerapan ion dalam polimer elektrolit (Zamri et al. 2014).

\section{SPEKTROSKOPI INFRAMERAH TRANSFORMASI FOURIER- PANTULAN PENUH KECIL (ATR-FTIR)}

Rajah 4 menunjukkan spektrum inframerah transformasi Fourier- pantulan penuh kecil (ATR-FTIR) yang digunakan untuk mengenal pasti interaksi yang berlaku antara garam $\mathrm{LiNO}_{3}$ dengan kumpulan berfungsi pada struktur kimia karboksimetil kitosan. Perubahan nombor gelombang bagi kumpulan berfungsi karbonil dan eter akan diberi tumpuan.

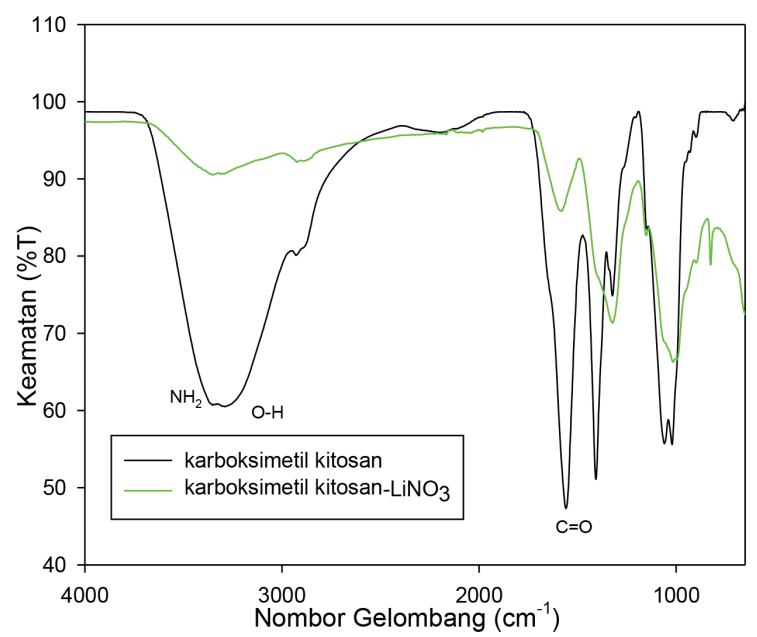

RAJAH 4. Spektrum ATR-FTIR bagi karboksimetil kitosan dan karboksimetil kitosan- $\mathrm{LiNO}_{3}$

Jika dibandingkan antara spektrum karboksimetil kitosan dengan karboksimetil kitosan- $\mathrm{LiNO}_{3}$ bagi regangan asimetri $\mathrm{C}=\mathrm{O}$, dapat diperhatikan bahawa nombor gelombang teranjak ke arah lebih rendah iaitu 1557 kepada $1586 \mathrm{~cm}^{-1}$. Ini menunjukkan bahawa penambahan garam $\mathrm{LiNO}_{3}$ menyebabkan nombor gelombang teranjak ke arah lebih tinggi. Interaksi yang berlaku dibuktikan dengan nilai daya pemalar. Nilai daya pemalar dikira berdasarkan kepada (7) dengan $v$ adalah nombor gelombang; c adalah halaju cahaya; $\mathrm{k}$ adalah daya pemalar dan $\mu$ adalah jumlah berat atom dalam gram. Jumlah berat atom dikira berdasarkan kepada (8) manakala (7) diringkaskan menjadi (9) (Pavia et al. 2008; Ravi et al. 2013). Nilai daya pemalar diringkaskan dalam Jadual 3.

$$
\begin{aligned}
& v=1 /(2 \pi c)(k / \mu)^{1 / 2} \\
& \mu=m_{l} m_{2} / m_{l}+m_{2} \\
& v=4.12(k / \mu)^{1 / 2}
\end{aligned}
$$

Jadual 2 juga menunjukkan kesan penambahan garam pada karboksimetil kitosan menyebabkan peningkatan nilai pemalar daya. Ini menunjukkan kepanjangan rantai adalah berkurangan antara karbon dan oksigen. Seperti yang diketahui, regangan asimetri adalah regangan yang berlaku pada arah berbeza. Oleh sebab interaksi elektrostatik adalah lebih kuat jika dibandingkan dengan interaksi ion dwikutub, maka panjang rantai karbon dan oksigen berkurangan (Mobarak et al. 2015).

JADUAL 2. Pemalar daya bagi regangan $\mathrm{C}=\mathrm{O}$ bagi karboksimetil kitosan dan karboksimetil kitosan- $\mathrm{LiNO}_{3}$

\begin{tabular}{lcc}
\hline \multirow{2}{*}{ Sampel } & \multicolumn{2}{c}{ Regangan $\mathrm{C}=\mathrm{O}$} \\
\cline { 2 - 3 } & $\begin{array}{c}\text { Nombor } \\
\text { gelombang }\left(\mathrm{cm}^{-1}\right)\end{array}$ & $\begin{array}{c}\text { Pemalar daya } \\
\left(\mathrm{N} \mathrm{cm}^{-1}\right)\end{array}$ \\
\hline Karboksimetil kitosan & 1557 & 9.79 \\
Karboksimetil kitosan- & 1589 & 10.19 \\
$-\mathrm{LiNO}_{3}$ & & \\
\hline
\end{tabular}

Jika dibandingkan antara spektrum karboksimetil kitosan dengan spektrum karboksimetil kitosan-LiNO dapat diperhatikan bahawa nombor gelombong bagi regangan simetri $\mathrm{C}=\mathrm{O}$ teranjak ke arah nombor gelombang lebih rendah iaitu 1428 kepada $1404 \mathrm{~cm}^{-1}$. Penambahan garam $\mathrm{LiNO}_{3}$ menyebabkan puncak yang mewakili regangan simetri $\mathrm{C}=\mathrm{O}$ juga melebar.

Peningkatan keamatan dapat diperhatikan pada nombor gelombang $1134 \mathrm{~cm}^{-1}$ yang mewakili regangan C-O dapat diperhatikan apabila garam litium ditambah ke dalam karboksimetil kitosan. Ini menunjukkan berlaku interaksi antara $\mathrm{Li}^{+}$dengan C-O (Sim et al. 2012). Secara keseluruhannya, pergerakan ion $\mathrm{Li}^{+}$di dalam karboksimetil kitosan adalah melalui interaksi dengan kumpulan karbonil dan kumpulan eter. Ini ditunjukkan melalui cadangan mekanisma pergerakan ion ditunjukkan pada Rajah 5.

\section{ANALISIS VOLTAMMETRI SAPUAN LURUS (LSV)}

Analisis voltammetri sapuan lurus (LSV) dijalankan untuk menentukan nilai voltan yang mampu ditahan oleh elektrolit. Nilai voltan ini penting dalam menentukan kesesuaian elektrolit untuk diaplikasikan di dalam sel elektrokimia seperti bateri. Rajah 6 menunjukkan graf arus melawan voltan bagi karboksimetil kitosan-30 bt. $\% \mathrm{LiNO}_{3}$. Dapat diperhatikan bahawa semakin tinggi voltan, arus meningkat dengan perlahan. Namun, apabila mencapai nilai voltan dan proses degradasi bermula, arus meningkat dengan lebih ketara. Keadaan yang sama juga dapat diperhatikan pada kajian yang dilakukan oleh Zhou et al. (2008) dan beliau berpendapat bahawa peningkatan arus secara perlahan adalah disebabkan oleh perubahan pada permukaan keluli tahan karat. Manakala peningkatan arus secara ketara dapat diperhatikan apabila ion di dalam elektrolit mula bergerak secara cepat kepada permukaan elektrod. Nilai voltan kestabilan kimia bagi ion $\mathrm{Li}^{+}$pada sistem karboksimetil kitosan - $\mathrm{LiNO}_{3}$ ini adalah $2.94 \mathrm{~V}$. 

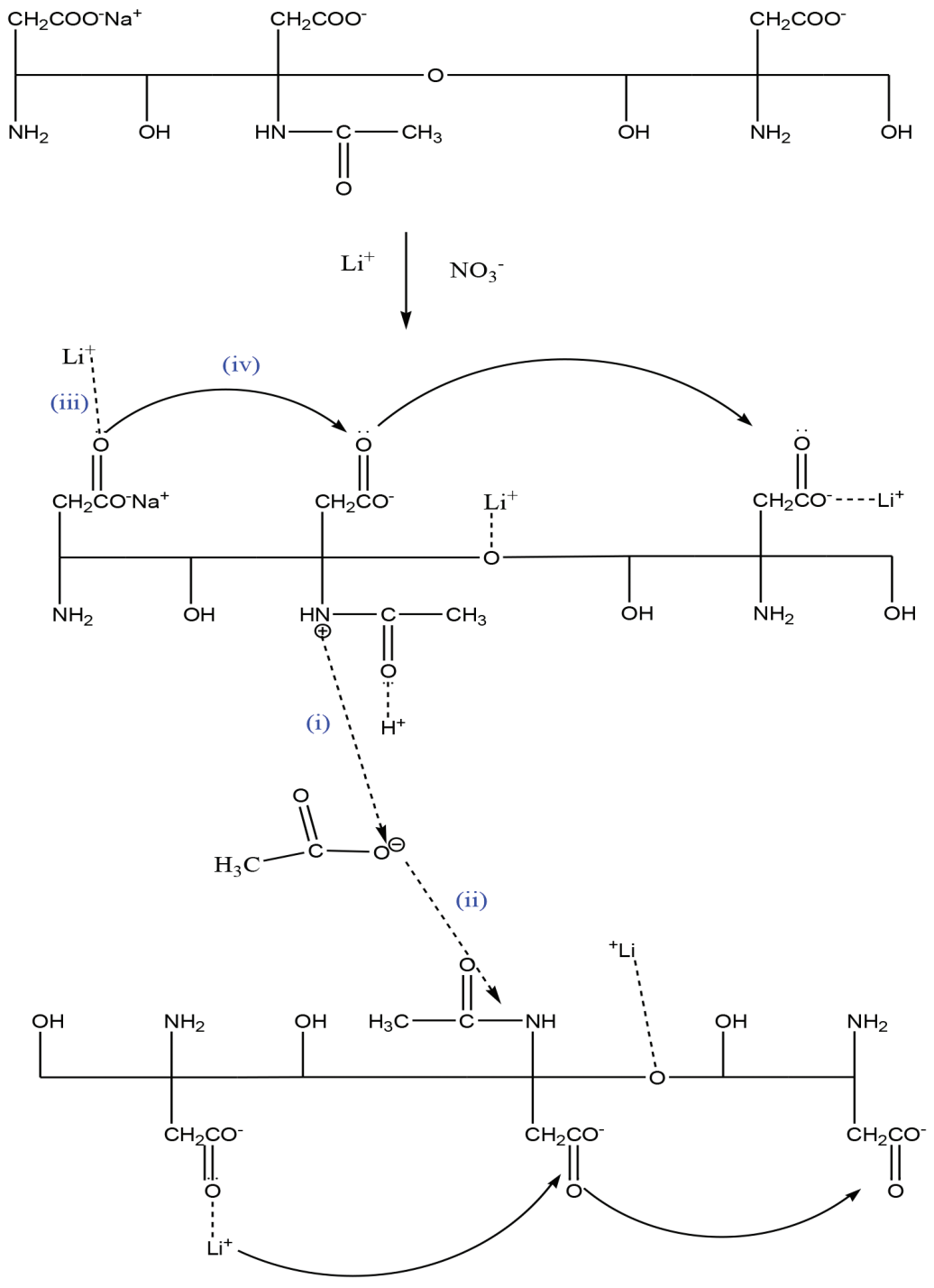

RAJAH 5. Cadangan mekanisme kebolehgerakan ion litium di dalam sistem karboksimetil kitosan (i) interaksi elektrostatik antara atom nitrogen (kumpulan amida) dengan ion asetat, (ii) pergerakan ion asetat pada atom nitrogen (kumpulan amida) yang lain (iii) interaksi ion dwikutub diantara ion litium dengan oksigen pada kumpulan karbonil dan eter (vi) pergerakan ion litium pada atom oksigen yang lain

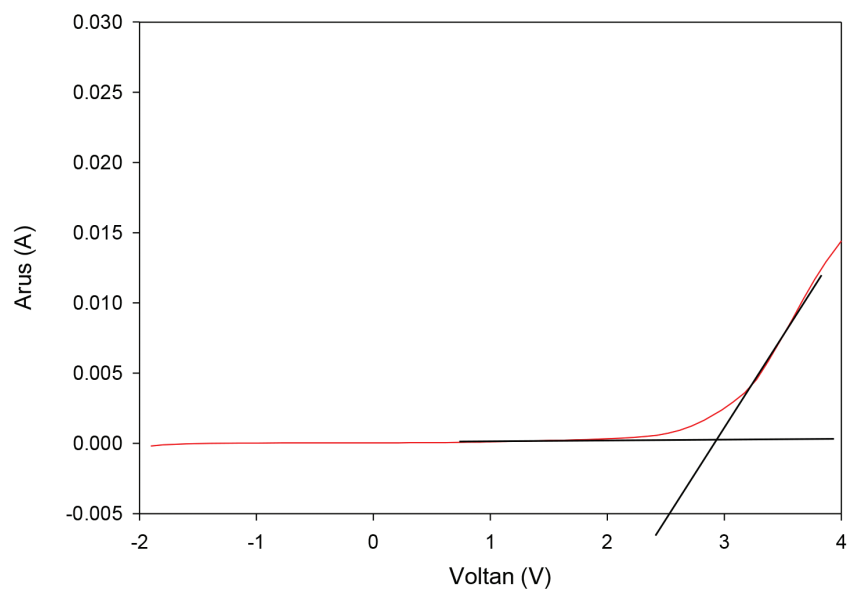

RAJAH 6. Graf kestabilan kimia bagi karboksimetil kitosan- $\mathrm{LiNO}_{3}$ 


\section{KESIMPULAN}

Kehadiran litium nitrat dalam karboksimetil kitosan mampu meningkatkan kekonduksian ion. Kekonduksian ion tertinggi yang dicapai adalah $8.44 \times 10^{-4} \mathrm{~S} \mathrm{~cm}^{-1}$ dengan kepekatan garam 30 bt. $\% \mathrm{LiNO}_{3}$ pada suhu bilik dan $5.25 \times 10^{-3} \mathrm{~S} \mathrm{~cm}^{-1}$ pada suhu $70^{\circ} \mathrm{C}$. Kestabilan kimia sistem karboksimetil kitosan $-\mathrm{LiNO}_{3}$ mencapai sehingga 2.94 V. Secara keseluruhan peningkatan kekonduksian ion dan kestabilan kimia yang tinggi dibantu oleh darjah penceraiaan ion yang baik dalam rantai karboksimetil kitosan $-\mathrm{LiNO}_{3}$.

\section{PENGHARGAAN}

Penulis ingin mengucapkan terima kasih kepada UKM. Kajian ini telah dijalankan di bawah tajaan peruntukan geran GGPM-2017-093.

\section{RUJUKAN}

Abdullah, O.G., Hanna, R.R., Salman, Y.A.K. \& Aziz, S. 2018. Characterization of lithium ion-conducting blend biopolymer electrolyte based on $\mathrm{CH}-\mathrm{MC}$ doped with $\mathrm{LiBF}_{4}$. Journal of Inorganic and Organometallic Polymers and Materials 28(4): 1432-1438.

Ahmad, N.H. \& Isa, M.I.N. 2016. Ionic conductivity and electrical properties of carboxymethyl cellulose $-\mathrm{NH}_{4} \mathrm{Cl}$ solid polymer electrolytes. Journal of Engineering Science and Technology 11(6): 839-847.

Croisier, F. \& Jérôme, C. 2013. Chitosan-based biomaterials for tissue engineering. European Polymer Journal 49(4): 780-792.

Denaro, A.R. 1987. Elektrokimia Permulaan. Kuala Lumpur: Dewan Bahasa dan Pustaka.

Hanibah, H., Ahmad, A. \& Hassan, N.H. 2014. A new approach in determining limiting molar conductivity value for liquid electrolyte. Electrochimica Acta 147: 758-764.

Hargreaves, S. 2013. The battery that grounded Boeing. http:// money.cnn.com/2013/01/17/technology/boeing-battery.

Hoek, C. 1995. Algae: An Introduction to Phycology. Cambridge: Cambridge University Press.

Hudson, S.M. \& Smith, C. 1998. Polysaccharides: Chitin and chitosan: chemistry and technology of their use as structural materials, Dlm. Biopolymers from Renewable Resources, disunting oleh Kaplan, D. New York: Springer. pp. 96-119.

Khanmirzaei, M.H. \& Ramesh, S. 2013. Ionic transport and FTIR properties of lithium iodide doped biodegradable rice starch based polymer electrolytes. International Journal of Electrochemical Science 8: 9977-9991.

Masykur, A., Santosa, S.J., Siswanta, D. \& Jumina, J. 2014. Synthesis of $\mathrm{Pb}$ (Ii) Imprinted carboxymethyl chitosan and the application as sorbent for $\mathrm{Pb}$ (Ii) ion. Indonesian Journal of Chemistry 14(2): 152-159.

Mobarak, N.N., Ahmad, A., Abdullah, M., Ramli, N. \& Rahman, M. 2013. Conductivity enhancement via chemical modification of chitosan based green polymer electrolyte. Electrochimica Acta 92: 161-167.
Mobarak, N.N., Jumaah, F.N., Ghani, M.A., Abdullah, M.P. \& Ahmad, A. 2015. Carboxymethyl carrageenan based biopolymer electrolytes. Electrochimica Acta 175: 224-231.

Mohamed, N.S., Subban, R.H.Y. \& Arof, A.K. 1995. Polymer batteries fabricated from lithium complexed acetylated chitosan. Journal of Power Sources 56: 153-156.

Osman, Z., Mohd Ghazali, M.I., Othman, L. \& Md Isa, K.B. 2012. AC ionic conductivity and DC polarization method of lithium ion transport in PMMA-LiBF4 gel polymer electrolytes. Physic 2: 1-4.

Pavia, D., Lampman, G., Kriz, G. \& Vyvyan, J. 2008. Introduction to Spectroscopy. Cengage Learning.

Ravi, M., Bhavani, S., Kiran Kumar, K. \& Narasimaha Rao, V.V.R. 2013. Investigations on electrical properties of PVP: KiO4 polymer electrolyte films. Solid State Sciences 19: 85-93.

Rudhziah, S., Ahmad, A. \& Mohamed, N. 2016. The effect of lithium iodide to the properties of carboxymethyl $x$-Carrageenan/carboxymethyl cellulose polymer electrolyte and dye-sensitized solar cell performance. Polymers 8(5): 163.

Sim, L.N., Majid, S.R. \& Arof, A.K. 2012. FTIR studies of PEMA/PVdF-HFP blend polymer electrolyte system incorporated with LiCF3SO3 salt. Vibrational Spectroscopy 58: 57-66.

Singh, R., Singh, P.K., Tomar, S.K. \& Bhattacharya, B. 2016. Synthesis, characterization, and dye-sensitized solar cell fabrication using solid biopolymer electrolyte membranes. High Performance Polymers 28(1): 47-54.

Wu, C., Wu, F., Bai, Y., Feng, T., Pan, C., Ye, L. \& Feng, G.Z. 2009. Preparation and characteristics of novel hyperbranched PEU-based gel polymer electrolytes. Journal of the Chilean Chemical Society 54(3): 299-301.

Xiong, S., Xie, K., Diao, Y. \& Hong, X. 2012. Properties of surface film on lithium anode with $\mathrm{LiNO}_{3}$ as lithium salt in electrolyte solution for lithium-sulfur batteries. Electrochimica Acta 83: 78-86.

Zamri, S.F.M., Latif, F.A.,Ali, A.M.M., Ibrahim, R., Kamaluddin, N. \& Hadip, F. 2014. Ionic conductivity and dielectric properties of $\mathrm{LiBF}_{4}$ doped PMMA/ENR 50 filled acid modified SiO2 electrolytes. Procedia Technology 15: 849855.

Zhou, D., Wang, G., Li, W., Li, G., Tan, C., Rao, M. \& Liao, Y. 2008. Preparation and performances of porous polyacrylonitrile-methyl methacrylate membrane for lithiumion batteries. Journal of Power Sources 184(2): 477-480.

School of Chemical Sciences and Food Technology

Faculty of Science and Technology

Universiti Kebangsaan Malaysia

43600 UKM Bangi, Selangor Darul Ehsan

Malaysia

*Corresponding author; email: nadhratunnaiim@ukm.edu.my

Received: 31 March 2018

Accepted: 17 May 2018 